\title{
Millstones as indicators of relative sea-level changes in northern Sicily and southern Calabria coastlines, Italy
}

\author{
G. Scicchitano ${ }^{\mathrm{a}, *}$, V. Lo Presti ${ }^{\mathrm{b}}$, C.R. Spampinato ${ }^{\mathrm{a}}$, M. Gasparo Morticelli ${ }^{\mathrm{b}}$, \\ F. Antonioli ${ }^{\mathrm{d}}$, R. Auriemma ${ }^{\mathrm{e}}$, L. Ferranti $^{\mathrm{c}}$, C. Monaco $^{\mathrm{a}}$ \\ a Dipartimento di Scienze Geologiche, Università di Catania, Corso Italia, 55, 95129 Catania Catane, Italy \\ ${ }^{\mathrm{b}}$ Dipartimento di Scienze Geologiche, Università di Palermo, Italy \\ ${ }^{\mathrm{c}}$ Dipartimento di Scienze della Terra, Università di Napoli Federico II, Italy \\ ${ }^{\mathrm{d}}$ ENEA - National Agency for New Technologies, Energy and Environment, Rome, Italy \\ ${ }^{\mathrm{e}}$ Dipartimento di Beni Culturali, Università del Salento, Italy
}

\section{A R T I C L E I N F O}

Article history:

Available online 8 September 2010

\begin{abstract}
A B S T R A C T
New data are presented for late Holocene relative sea-level changes in two coastal sites of Sicily and Calabria, southern Italy. Reconstructions are based on precise measurements of submerged archaeological remains that are valuable indicators of past sea-level position. The archaeological remains are millstone quarries carved on sandstone coastal rocks and nowadays partially submerged which, to the authors' knowledge, are used for the first time as sea-level markers. Millstones of similar typology are located on the coast of Capo d'Orlando (northern Sicily) and Capo dell'Armi (southern Calabria). When the archeologically-based sea-level position is compared with the shoreline elevation provided by geological markers (Holocene beachrock, Late Pleistocene marine terraces), a refined understanding of relative sea-level changes and rates of vertical tectonic movements for these coastline locations is gained. (C) 2010 Elsevier Ltd and INQUA. All rights reserved.
\end{abstract}

\section{Introduction}

Archaeological remains in areas of small tidal range such as the Mediterranean Sea can provide significant information on relative sea-level changes during the last millennia. By using archaeological coastal structures whose successful functioning is well attested, a precisely defined relationship to sea level at time of construction is obtained. Along the Mediterranean shores, the historically increasing sophistication of human development has led to there being a number of archaeological remains that can be used to establish constraints on relative sea level. Several archaeological structures have been considered as palaeo-sea level markers: fish ponds, docks, piers, quarries, tombs, pavements, and bollards have furnished important improvements in the accurate evaluation of relative sea-level change during the last millennia (Schmiedt, 1966, 1972; Flemming, 1969; Flemming and Webb, 1986; Lambeck et al., 2004; Anzidei et al., 2006; Antonioli et al., 2007; Scicchitano et al., 2008; Auriemma and Solinas, 2009; Ferranti et al., in this issue).Quarries, in particular, may represent an important marker for the followings reasons: (i) their abundance along the

\footnotetext{
* Corresponding author.

E-mail address: gianfrancoscicc@hotmail.com (G. Scicchitano).
}

Mediterranean coast, (ii) the large use for a long period of the same kind of architectural structures, (iii) the transport techniques often operated by boats of different cabotage relating to the dimension of the blocks extracted and, as a consequence, (iv) their implicit relation with the sea level at the time of their use that affords a reconstruction of the palaeo-sea level.

Different typology of quarries can be distinguished in historical times. One of these is represented by quarries for the extraction of millstones for grinding olives during oil production, that in southern Italy is documented since around 2500 BP (Amouretti, 1986; Amouretti and Brun, 1993; Brun, 1997). Millstone dimensions and shapes were strictly related to the crusher systems used. One of these was characterized by the use of cylindrical or slightly truncated-cone shape wheels that turned perpendicularly above a subjacent horizontal wheel of similar size placed above a masonry base (Amouretti, 1986; Hadjisavvas, 1992; Brun, 1997; Rosada, 2007). This system is attested since the beginning of the Hellenistic period in Israel and Cyprus, and largely spread within the whole Mediterranean basin from the Roman to the modern age, until the XIX century, when traditional crushers were progressively abandoned (Amouretti and Brun, 1993). Millstones quarries developed mostly along the shore, as open-work, and on terrace levels. The heavy millstones were transported almost exclusively by river and sea, land transport being too complex and expensive (Bessac, 
1986). Coastal quarrying was the best logistic solution to the difficulties of stone transport, and is noted in literary sources and archaeological evidence (Orlandos, 1968, Fig. 14; Dworakowska, 1975; Rockwell, 1992, Fig. 56; Kozelj and Wurch Kozelj, 1993, Fig. 1, 4, 41; Felici Buscemi and Felici, 2004).

Various examples of millstone quarries are found in the southern coasts of Italy. Palinuro in Campania, Crotone, Roccella Ionica, Capo dell'Armi in Calabria, Capo d'Orlando, Giardini-Naxos in Sicily, represent the costal sites where millstone quarries, showing similar architectural features, are present. Despite their large geographical extent and their occurrence strictly related to the coastline, millstone quarries have not yet been used as archaeological markers for evaluation of sea-level changes during the late Holocene.

The aim of this paper is the analysis of two different millstone quarries located at Capo d'Orlando in northern Sicily and Capo dell'Armi in southern Calabria (Fig. 1), in order to place constraints on the recent sea-level change at these sites based upon the age and functional height derived from the quarries. The interpretation of their former functional height, at the time of their excavation, provides data on the relative position of land and sea. These data, when compared with modeled Holocene sea-level rise curves (Lambeck et al., 2011) based on eustatic and glacio-hydro-isostatic dynamics, provide accurate evaluations of vertical tectonic movements that affected the coastlines during the last millennia. As it was difficult to date the studied archaeological sites, analyses of morphological markers related to older sea levels, such as marine terraces, palaeo-shorelines, marine deposits and beachrocks, allowed better determination of vertical tectonic uplift rates that affected the Capo d'Orlando and Capo dell'Armi coastal sectors and, consequently, to constrain the age of the millstone quarries.

\section{Geological setting}

The studied sites are located in the southernmost portion of the Calabrian arc (Fig. 1). This prominent orogenic domain connects the
Apennines and the Sicilian-Maghrebian orogens that developed during the Neogene-Quaternary Africa-Europe collision and Ionian slab roll-back (Malinverno and Ryan, 1986; Dewey et al., 1989; Boccaletti et al., 1990). Since Pliocene times, the contractional structures of the hinterland part of the orogen were superseded by extensional faults (Fig. 1), both longitudinal and transversal with respect to the arc, which caused the fragmentation into structural highs and marine sedimentary basins (Barone et al., 1982; Ghisetti and Vezzani, 1982; Kastens et al., 1987; Trincardi et al., 1987; Pepe et al., 2000, 2003). In eastern Sicily and Calabria, the contractional processes along the chain and the collapse at the rear have been followed by strong uplifting that is recorded by the flights of Quaternary marine terraces (Dumas et al., 1982; Ghisetti, 1984; Valensise and Pantosti, 1992; Westaway, 1993; Miyauchi et al., 1994; Bianca et al., 1999; Catalano and De Guidi, 2003; Tortorici et al., 2003). The elevation of marine terraces and their offset across the main faults has been used to establish the relative contribution of regional and fault-related sources to uplift. According to Westaway (1993), $1.67 \mathrm{~mm} / \mathrm{y}$ of post-Middle Pleistocene uplift of southern Calabria was partitioned into $\sim 1 \mathrm{~mm} / \mathrm{y}$ due to regional processes and the residual to displacement on major faults. Shorter-term uplift-rate estimates are provided by raised Holocene beaches, terraces and tidal notches (Firth et al., 1996; Pirazzoli et al., 1997; Stewart et al., 1997; Rust and Kershaw, 2000; Antonioli et al., 2003, 2006; De Guidi et al., 2003; Ferranti et al., 2007).

The strong regional uplifting of the whole Calabrian Arc has been coupled with an important geodynamic change occurred in the region during the Middle Pleistocene, signalled by the end of frontal thrust displacement and stalling of subduction of the Ionian plate beneath the Tyrrhenian domain (Westaway, 1993; Wortel and Spackman, 2000; Goes et al., 2004). In this context, the belt between the southernmost sector of the Aeolian archipelago and north-eastern Sicily (Fig. 1), dominated by the Vulcano-Tindari fault system (Lanzafame and Bousquet, 1997; Billi et al., 2006), currently separates two geodynamic regimes (Argnani et al., 2007;

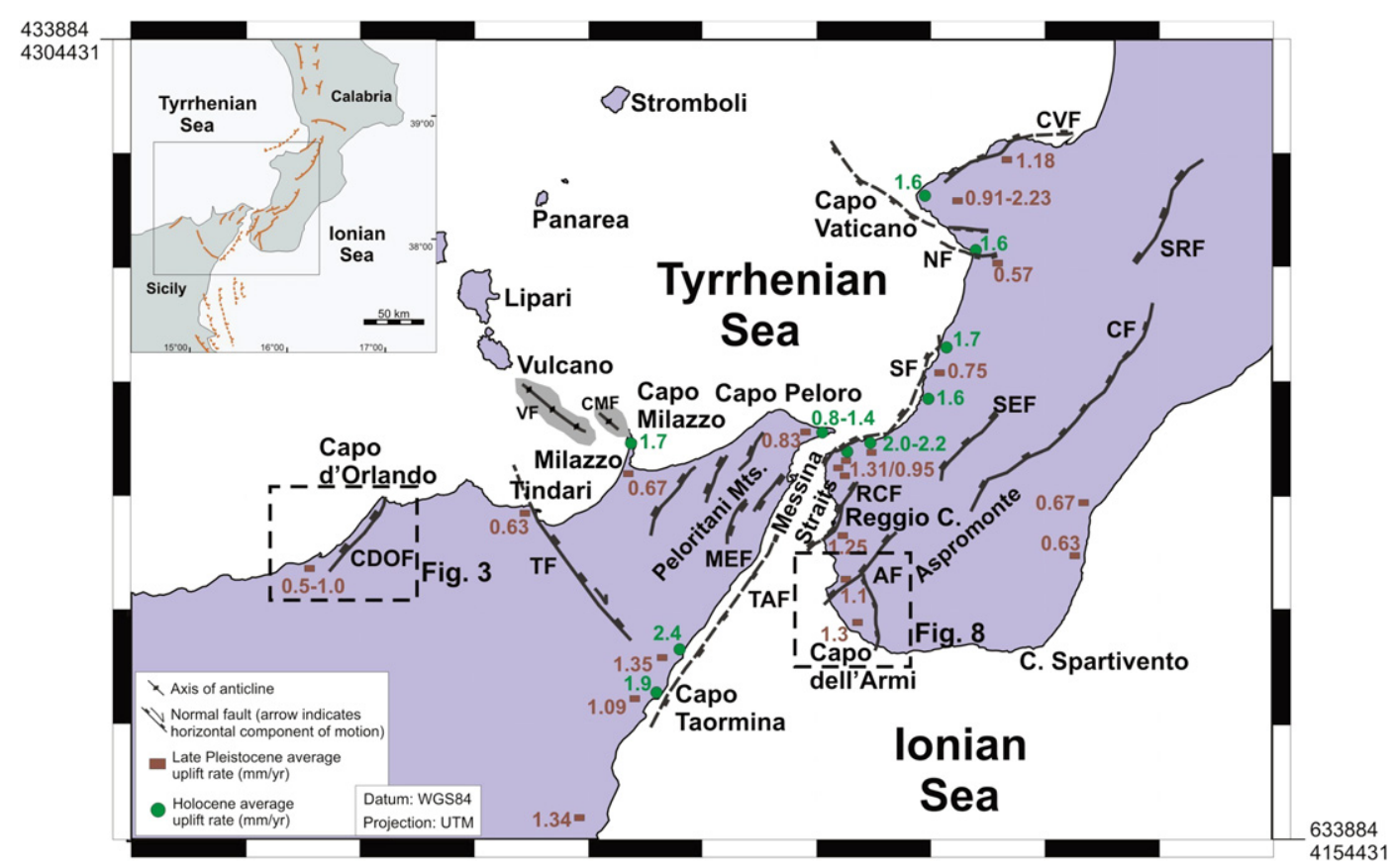

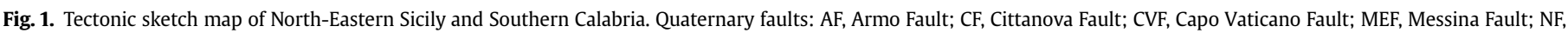

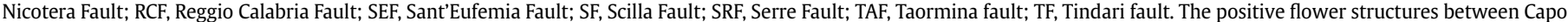

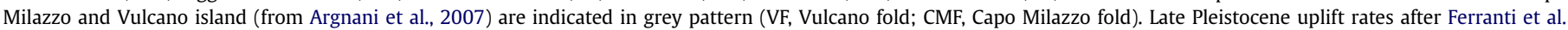
(2006), Holocene uplift rates after Antonioli et al. (2009). 
Mattia et al., 2008, 2009). To the east, an extensional domain is dominated by incipient rifting that, characterized by strong crustal seismicity and volcanism, cuts across the Strait of Messina reactivating the normal faults of the Tyrrhenian sector of Calabria and the Malta Escarpment in the eastern Sicily offshore (Siculo-Calabrian rift zone; Monaco and Tortorici, 2000). Active WNW-ESE extension is documented by focal mechanisms of crustal earthquakes (Pondrelli et al., 2006), structural studies (Tortorici et al., 1995; Monaco et al., 1997; Jacques et al., 2001; Ferranti et al., 2007), and geodetic velocities (D'Agostino and Selvaggi, 2004; Mattia et al., 2009). To the west of the Vulcano-Tindari fault system, the southern Tyrrhenian Sea margin is characterized by moderate crustal seismicity, mostly related to an E-W oriented, regional belt of contraction and dextral shear (Nicolich et al., 1982; Boccaletti et al., 1990; Nigro and Sulli, 1995; Gueguen et al., 2002; Giunta et al., 2004). Focal mechanisms are mostly characterized by strike-slip and reverse-oblique kinematics compatible with lowdip NW-SE to NNW-SSE trending P-axes (Frepoli and Amato, 2000; Neri et al., 2005; Pondrelli et al., 2006; Giunta et al., 2009), roughly consistent with the general convergence between the European and African plates (Hollenstein et al., 2003; Lavecchia et al., 2007; Ferranti et al., 2008).

Capo dell'Armi is located on the south-eastern, Calabrian shore of the Messina Straits, about $20 \mathrm{~km}$ south of the town of Reggio di Calabria (Fig. 1). The Messina Straits are bounded by normal faults, marked by well preserved scarps, which dissect several, strongly uplifted, Pleistocene marine terraces and Holocene shorelines (Valensise and Pantosti, 1992; Ferranti et al., 2007). This area was struck by an $M \sim 7$ earthquake on December 28,1908, whose source has been related to normal faulting on planes trending nearly parallel to the Straits, albeit with different locations and dipping (see Valensise and Pantosti, 1992; Amoruso et al., 2002 and references therein). The displacement caused a coseismic down-warping of the area which was documented by leveling surveys performed one year before and immediately after the earthquake (Loperfido, 1909). The studied site is located at the footwall of the $18 \mathrm{~km}$-long SW-NE trending Armo normal fault (Ghisetti, 1981, 1984). This Quaternaryage fault bounds the south-eastern margin of the Reggio Calabria basin from the crystalline upraised block of the Aspromonte ridge (Fig. 1). In this area, the MIS 5.5 terrace deposits include rich Strombus bubonius assemblages, as in the case of Ravagnese and Bovetto sites, where deposits are found at elevations of 130-140 m (Gignoux, 1913; Bonfiglio, 1972), and Nocella, where they crop out at an elevation of about $175 \mathrm{~m}$ (Dumas et al., 1987). The age attribution of these deposits to the 125 ka high-stand has been confirmed by TL determinations (Balescu et al., 1997). Recent activity of the Armo fault is shown by raised Holocene beach rock sediments found at its footwall by Pirazzoli et al. (1997), whose characteristics and age are discussed in detail in this paper.

Capo d'Orlando is located along the Tyrrhenian shore of northeastern Sicily about $70 \mathrm{~km}$ west of the town of Messina (Fig. 1). It is part of the footwall of a Pleistocene northwest-dipping normal fault (Carbone et al., 1998), here named Capo d'Orlando fault (Fig. 1), that controlled the geomorphologic evolution of the coast to the west of the promontory. The effects of regional and local Pleistocene tectonic processes in this area have been recorded by flights of terraces extending along this coastline. Different uplift rates have been determined by using morphological and paleontological markers. Stratigraphic and morphologic correlations with the MIS 5.5 terrace provided an uplift rate of $0.50 \mathrm{~mm} / \mathrm{y}$ in the Tindari promontory, $25 \mathrm{~km}$ to the east of Capo D'Orlando (Gliozzi and Malatesta, 1982; Bonfiglio et al., 2010). However, bones of dated continental mammals found at Acquedolci (Bada et al., 1991), $15 \mathrm{~km}$ to the west of Capo d'Orlando, allowed stratigraphic and morphologic correlations with the MIS 5.5 terrace in the Capo d'Orlando area and to establish lower rates of uplifting (see below). Longerterm uplift rates were obtained by 0.5-1.0 Ma marine deposits outcropping at about $500 \mathrm{~m}$ a.s.l. in the Naso village, $5 \mathrm{~km}$ to the south-east of this coastline (Catalano and Di Stefano, 1997). Present tectonic activity is documented by historical seismicity (Mongitore, 1743; Incudine, 1882; Working Group CPTI, 2004), with epicenters of the major earthquakes (I = VII - IX) located along a SW-NE trending alignment extending south of Naso (Fig. 3).

\section{Millstones: historical exploitation}

The use of millstones for grinding olives and oil production (Fig. 2a) was a fundamental technological innovation that reflects
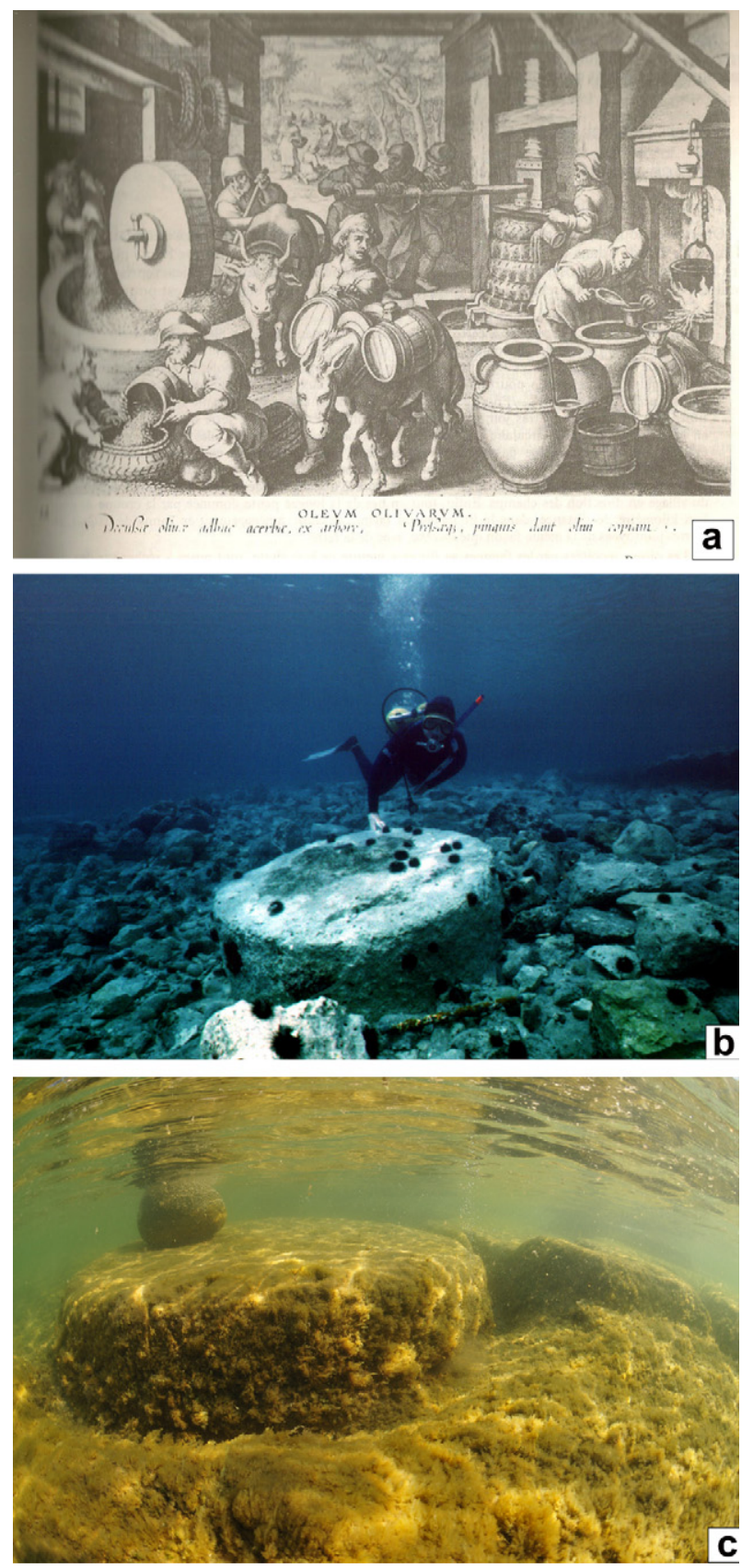

Fig. 2. (a) Old drawing reproducing millstones for grinding olives and oil production (from Amouretti, 1986). (b) Large stone disk (likely a millstone) retrieved in a shipwreck at Torre Santa Sabina bay (Adriatic coast of Apulia). (c) Submerged millstone at Capo D'Orlando (Tyrrhenian coast of north-eastern Sicily). 


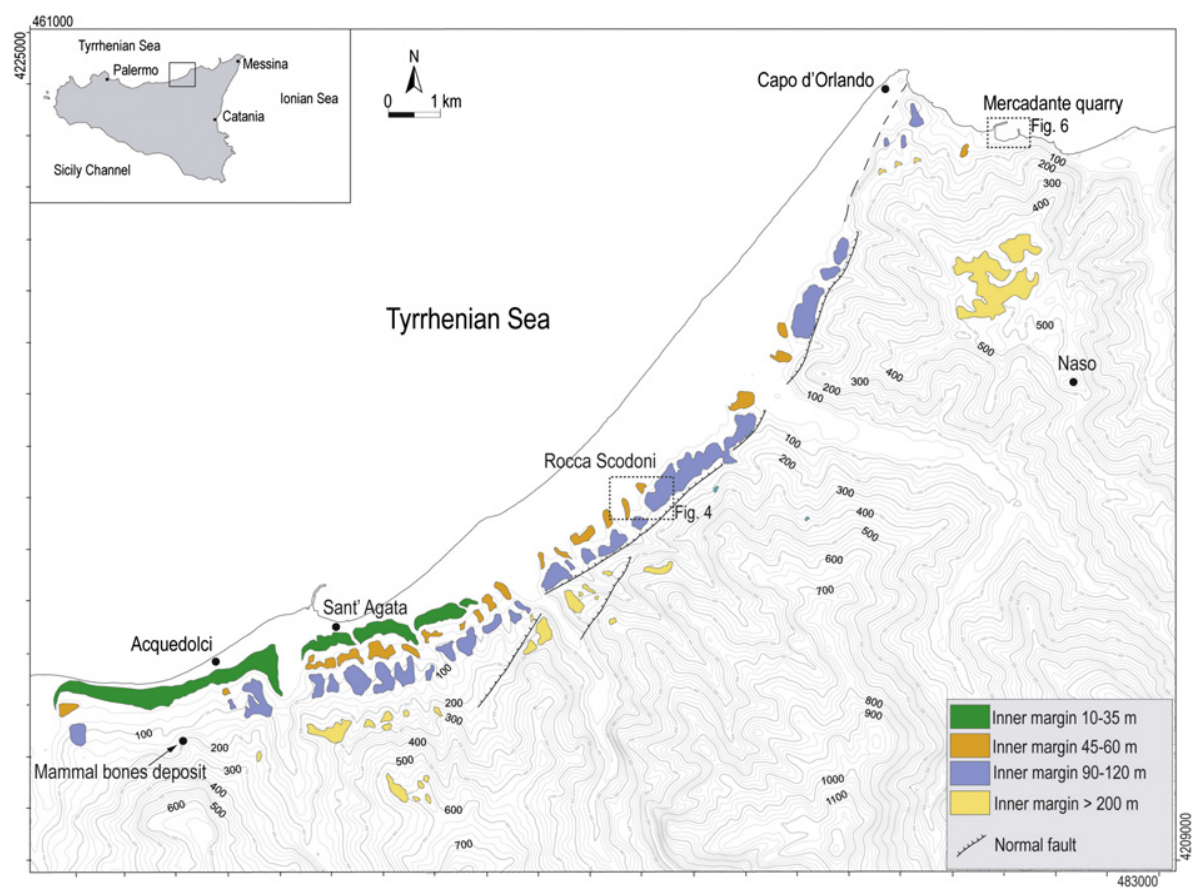

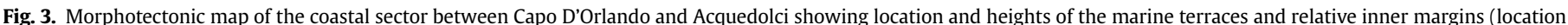
in Fig. 1).

a marked economical improvement at the end of the archaic era, which in southern Italy occurred around 2500 BP (Amouretti, 1986; Amouretti and Brun, 1993; Brun, 1997). However, large uncertainties exist in the attempt to give archaeological age constraints to the millstones quarries, mostly because these artefacts were reused after the crusher closing down and also because of the limited knowledge on the Mediterranean rural archaeology.

The earlier records come from Chios (mid V century B.C.), Olinthos (IV century B.C.) and Corinto (before 146 B.C.) in Greece, and Maresha in Palestine (III century B.C.), and they refer to the first and most ancient type of crusher, the "trapetum" (from the Greek trapetés) described by Catone (De agricultura, 20-22; Res Rusticae, 23-24-25). The trapetum is formed by one or two grinding wheels with hemispherical or truncated- and rounded-cone shapes ("orbes"), that revolved inside a bowl (Boardman, 1958-1959; Moritz, 1958; Adam, 1984; Amouretti, 1986; Foxhall, 1993; Kloner and Sagiv, 1993; Brun, 1997; Rosada, 2007). A younger crusher system used a cylindrical or slightly truncated-cone shape vertical wheel ("mola") that turned on a subjacent horizontal wheel ("sottomola") of similar size placed above a masonry base (Amouretti, 1986; Hadjisavvas, 1992; Brun, 1997; Rosada, 2007). This system is documented since the beginning of the Hellenistic period in Israel and Cyprus, and largely spread within the whole Mediterranean basin from the Roman to the modern age, until the XIX century, when traditional crushers were progressively abandoned (Amouretti and Brun, 1993). This crusher system seems identifiable with the oil grindstone ("mola olearia") mentioned by Columella, who preferred it to the other systems (XII, 52,3). The $m$. olearia, as the well known case from Settefinestre (Carandini, 1985, Fig. 349) and other rural (Mattingly and Hitchner, 1993; Frankel, 1993; Busana et al., 2009) or urban (e.g. Umag, Croatia; Matijašić, 2007) settlements attest, was operated by slaves or donkeys. A single mola was associated with numerous presses (torcularia): this is another reason for their limited number. The quarried millstones of Capo dell'Armi and Capo d'Orlando are identified as the mole or sottomole of this second type. A third millstone type exists, with taller and wider cylindrical wheels, diffused only in North Africa during the
Roman age (likely corresponding to the rotula of Roman literary sources). A variation of this type is only known from two sites (Volubilis in Marocco and Munigua in Spain), and had a cylindrical stem and rounded top (Brun, 1997). The second type, the oil grindstone $(m$. olearia), is very similar to crushers of the mediaeval (Comet, 1993) and modern age, active in Sicily until a few decades ago, and described by Bianca at the end of the XIX century (Acquaviva, 1995).

The dimension of the Roman, mediaeval and modern specimens of mola are analogous to those of Capo d'Orlando and of Capo dell'Armi. The Roman cylindrical olive millstones (mole or sottomole) have a diameter that varies from 1.00/1.10 m (Umag: Matijašić, 2007), to $1.15 \mathrm{~m}$ (Settefinestre, height 0.35 ), $1.50 \mathrm{~m}$ (Marea, Egipt; Cosa, sottomola; Antella, Firenze, sottomola: Carandini, 1985), 1.62 m (Desenzano, sottomola: Scagliarini Corlàita, 1994), up to $2.37 \mathrm{~m}$ (Granaraccio, Tivoli, sottomola made of two pieces: Carandini, 1985). Specimens from the XIX century Sicily crushers have diameters of $1.30 \mathrm{~m}$. As regards the modern age, a slight change in dimension is perhaps outlined by Greek samples. From the Middle Age to the XVII century, a single large-sized wheel (over $1.5 \mathrm{~m}$ of diameter and $0.4-0.5 \mathrm{~m}$ of thickness), played by an animal, seems to prevail. Later, millstones of smaller dimensions (from 0.60 to $1.20 \mathrm{~m}$ of diameter, and $0.20-0.30 \mathrm{~m}$ of thickness) were produced (Amouretti, 1986). Notwithstanding size variations, their origin from the Greek-Roman m. olearia is evident.

The large extent of coastal exploitation is confirmed by the finding of several shipwrecked loads of millstones, of prevailing Greek-Roman (simple manual rotating type or adjustable rotating type and "Pompeian" type) and subordinately of medieval or postmedieval age (Beltrame and Boetto, 1997). As an instance, a large stone disk (likely a millstone) with dimensions analogous to those of the olive millstones of Capo d'Orlando (Fig. 2c) and Capo dell'Armi samples, was retrieved in a shipwreck within the shallow sea-bottom of Torre S. Sabina bay on the southern Adriatic coast (Fig. 2b; Auriemma, 2007). Finally, another cylindrical millstone quarry is noted at Letoianni, near Capo Taormina (A. Ollà and E. Felici, personal communication). 
In summary, the second type of oil grindstone, the $m$. olearia, comparable to those in the quarries under consideration, was in use at least from the Hellenistic age, or, given the large dimensions, from the Roman Imperial age (I-II century A.D) to the XVII century. Because of the lacking chronological constraints for carving activity in quarries, constraints on age estimates for the studied millstones use geological (Holocene and MIS 5.5 age) vertical tectonic displacement rates of the coast.

\section{Methods}

Measurements of the current heights of archaeological and geomorphological markers with respect to the current sea level at the time of the survey were performed by an invar rod mechanical system. Data have been corrected for tides and pressure relative to mean sea level (MSL) using data from the tide gauges of Milazzo and Reggio di Calabria (Fig. 1; http://www.wxtide32.com and from the meteorological site www.wunderground.com).

In order to relate the archaeological structures to ancient mean sea levels, the former functional height at each location was defined. The functional height is defined as the height of a specific architectural part of an archaeological structure with respect to the mean sea level at the time of its construction and use. The height depends on the type of structure, its use, and the local tide amplitudes. These parameters also define the minimum height of the structure above the local highest tides. For quarries located in south-eastern Sicily, Scicchitano et al. (2008) proposed a minimum elevation of their original floor at $0.30 \mathrm{~m}$ above high tide to be always dry, which implies a minimum functional height of $0.60 \mathrm{~m}$ with respect to mean sea level. This estimate is in agreement with the observations collected at other coastal archaeological sites in the central Mediterranean area (Lambeck et al., 2004; Antonioli et al., 2007). For the millstone quarries found at Capo d'Orlando and Capo dell'Armi, analogous similar functional height seems to be realistic and a minimum elevation of their original floor at $0.60 \mathrm{~m}$ above the mean sea level has been assumed (Table 1). The floor of the quarry is considered to coincide with the base of the lowest relic wheel still attached to the bedrock because it never went extracted.

As regards the beach rocks surveyed along the coast, as well as in the area directly offshore, diving operations have been carried with the aim of mapping the base of the sedimentary body. Depths were measured by using a digital depth gauge. Tectonic uplift-rate estimations were performed for the beach rock at Capo dell'Armi considering the elevation radiometrically-dated samples. Finally, the elevation of morphological and sedimentological markers from marine terraces has been estimated from detailed topographic maps ( $1: 10,000$ scale).

\section{Geological and archaeological markers}

\subsection{Capo d'Orlando}

The coastal sector between Capo d'Orlando and Acquedolci (15 km to the southwest of the Capo, Fig. 3) shows morphological and sedimentological markers of Pleistocene sea level high-stands. Marine abrasion platforms with associated deposits have been observed at distinct elevations. In the Capo d'Orlando area, a higher depositional terrace is located at an elevation of $\sim 500 \mathrm{~m}$ a.s.l. Analysis of foraminifera and nannoplankton attributed an age between 550 and 984 ka to the terraced deposits (Catalano and Di Stefano, 1997). Hugonie (1974, 1979, 1982) and Robillard (1975), identified seven orders of marine terraces associated with three important abrasion platforms at lower elevations of between 220 and $30 \mathrm{~m}$ a.s.l. A sedimentary wedge rich in bones of continental mammals was found at the base of a carbonate palaeo-cliff in the Acquedolci area between 110 and $130 \mathrm{~m}$ a.s.l. (Fig. 3; Bonfiglio, 1989). Isoleucine epimerization dating of bones yielded ages of $200 \pm 40 \mathrm{ka}$ (Bada et al., 1991).

The geomorphologic survey recognized four orders of marine terraces located at elevations of $200 \mathrm{~m}, 120-90 \mathrm{~m}, 60-45 \mathrm{~m}$, and 35-10 m a.s.l. (Fig. 3). Between Acquedolci and Capo d'Orlando (Rocca Scodoni, Figs. 3 and 4 ) the $45-60 \mathrm{~m}$ high terrace is characterized by an up to $10 \mathrm{~m}$ thick marine deposit constituted by coarse polygenic conglomerates, micro-conglomerates and crossed lamination sands in a fining-upward sequence (Fig. 5a, b). Here, the inner margin of this terrace has been recognized at $\sim 45 \mathrm{~m}$ a.s.l. and abuts an ancient cliff showing several Lithodomus holes (Fig. 5d), with some preserved fossilized shell inside, and other biological remains. A shell of Spondylus sp. (Fig. 5c) was collected in physiologic position from this deposit for geochronological analysis.

The Capo d'Orlando area, where the literary tradition places Agathyrnus, the legendary town founded by the homonymous son of Eolo, God of Winds, is characterized by several archaeological settlements since the late Bronze Age (Scibona, 1985; Pinzone, 2004; Spigo, 2004a). Thanks to its strategic position, the site was continuously colonized from the Archaic to the Hellenistic age as indicated by votive materials, probably belonging to a sanctuary, and by a IV-III century B.C. necropolis (Bonanno, 2004). Moreover, Roman remains are well-known and are represented by scattered material areas and inscriptions. In the Bagnoli-San Gregorio area (near the Mercadante quarry, Fig. 6) there was a little harbour, as the underwater finds indicate, and a probable villa and/or mansion with a thermal complex dated between the III and V century A.D. The complex bears evidence of damages possibly caused by one or more earthquakes (Spigo, 1995, 2004b; Ollà, 2004; Spigo et al., 2004).

Along the coast enclosed by the modern Bagnoli harbour, an ancient quarry of grinding wheels for oil (known as Mercadante

Table 1

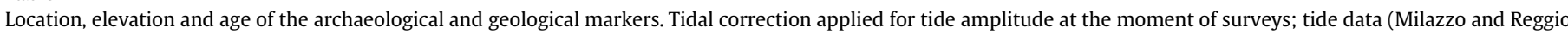

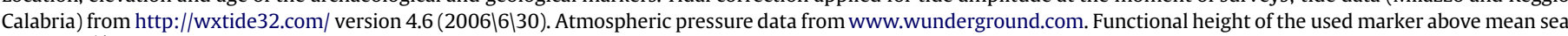

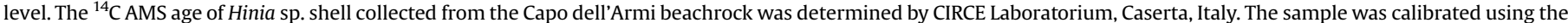

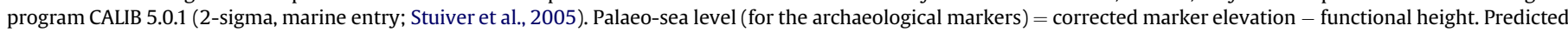

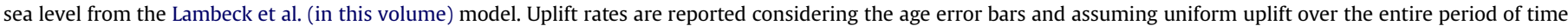
considered, and hence represent time-averaged estimates.

\begin{tabular}{|c|c|c|c|c|c|c|c|c|c|c|c|c|}
\hline Site & Marker & $\begin{array}{l}\text { Measured } \\
\text { elevation (m) }\end{array}$ & $\begin{array}{l}\text { Measurement Time } \\
\text { (yy/mm/dd/hh) }\end{array}$ & $\begin{array}{l}\text { Tide } \\
(\mathrm{m})\end{array}$ & $\begin{array}{l}\text { Atmospheric } \\
\text { pressure } \\
\text { (mbar) }\end{array}$ & $\begin{array}{l}\text { Corrected } \\
\text { marker } \\
\text { elevation }(\mathrm{m})\end{array}$ & $\begin{array}{l}\text { Functional } \\
\text { height (m) }\end{array}$ & $\begin{array}{l}{ }^{14} \mathrm{C} \text { AMS } \\
\text { age } \\
(\mathrm{yr} \mathrm{BP})\end{array}$ & $\begin{array}{l}\text { Age } \\
\text { (yr cal } \\
\text { BP) }\end{array}$ & $\begin{array}{l}\text { Palaeo-sea } \\
\text { level (m) }\end{array}$ & $\begin{array}{l}\text { Predicted } \\
\text { sea level } \\
(\mathrm{m})\end{array}$ & $\begin{array}{l}\text { Uplift rate } \\
\mathrm{mm} / \mathrm{yr}\end{array}$ \\
\hline $\begin{array}{l}\text { Capo } \\
\text { D'Orlando }\end{array}$ & Quarry & -0.40 & $2009 / 09 / 15 / 07$ & 0.31 & 1013 & -0.09 & 0.60 & - & - & -0.69 & $\begin{array}{l}\text { see } \\
\text { Table } 2\end{array}$ & $\begin{array}{l}\text { see } \\
\text { Table } 2\end{array}$ \\
\hline $\begin{array}{l}\text { Capo } \\
\text { Dell'Armi }\end{array}$ & Quarry & -0.40 & 2009/09/15/11 & 0.24 & 1013 & -0.16 & 0.60 & - & - & -0.76 & $\begin{array}{l}\text { see } \\
\text { Table } 2\end{array}$ & $\begin{array}{l}\text { see } \\
\text { Table } 2\end{array}$ \\
\hline $\begin{array}{l}\text { Capo } \\
\text { Dell'Armi }\end{array}$ & $\begin{array}{l}\text { Beach } \\
\text { rock }\end{array}$ & $0.70 \pm 1.00$ & $2009 / 03 / 08 / 12$ & 0.20 & 1013 & $0.50 \pm 1.00$ & - & $4760 \pm 27$ & $4870-5137$ & $0.50 \pm 1.00$ & -4.55 & $1.01 \pm 0.25$ \\
\hline
\end{tabular}




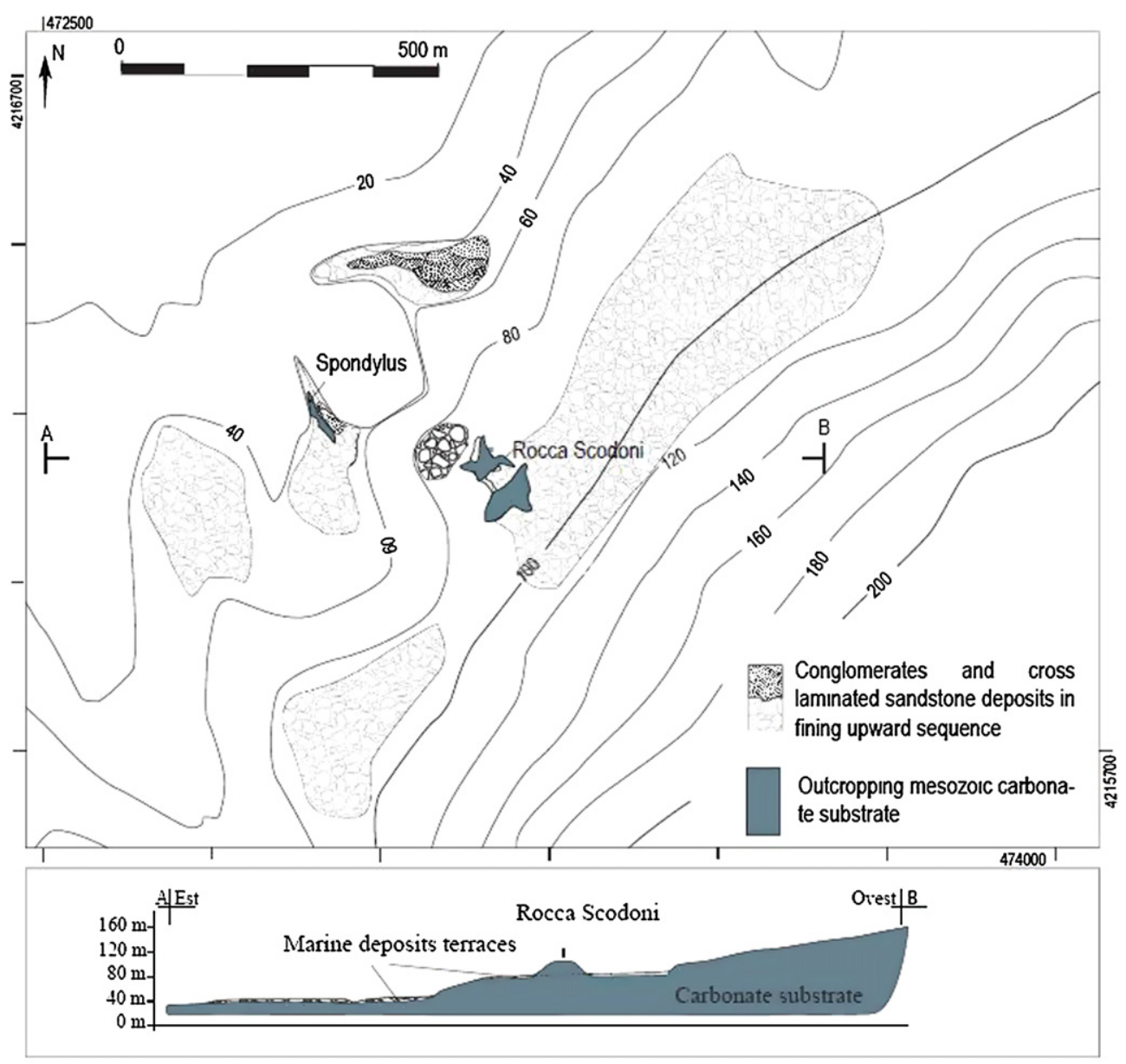

Fig. 4. Detailed map and transect of Rocca Scodoni area (location in Fig. 3).

quarry) has been found (Fig. 6). The quarry is characterized by circular holes carved into the bedrock (Upper Oligocene-Lower Miocene Stilo-Capo d'Orlando sandstone, Carbone et al., 1998) in order to extract rock grinding wheels for oil production (Fig. 7a). The holes are clustered into an exploitation field, about $110 \mathrm{~m}$ long and $30 \mathrm{~m}$ wide, parallel to the present coastline and extending from the shoreline down to $-0.6 \mathrm{~m}$ depth. The holes are up to $1.5 \mathrm{~m}$ dimension. All are presently submerged and they commonly show near-complete wheels preserved inside the holes (Fig. 7a and b). Elevation of the base of the extraction cuts of the holes hosting the non-extracted wheels has been measured with respect to the present sea level. Data have been corrected for tide and pressure at the time of the survey. The deepest structure has been found at a corrected depth of $-0.09 \mathrm{~m}$ (Table 1 ), and it is represented by a sub-circular hole $1.35 \mathrm{~m}$ large associated to a well preserved about $30 \mathrm{~cm}$ thick wheel. Seawards, the seabed appears flat for a distance of $18 \mathrm{~m}$, where at about $-1 \mathrm{~m}$ depth a series of small steps deepens the bottom down to about $-3.5 \mathrm{~m}$ depth (see transect in Fig. 6). Unfortunately, archaeological structures related to ship mooring, such as bollards or docks, have not been observed. Considering a depth for the deepest grinding wheel of $-0.09 \mathrm{~m} \mathrm{~b} \mathrm{~s} 1$, and taking into account a functional height for the site of $0.60 \mathrm{~m}$, it is possible to reconstruct a palaeo-sea level of $-0.69 \mathrm{~m}$ below present sea level for the Mercadante quarry.

\subsection{Capo dell'Armi}

The eastern side of the Messina Straits (Fig. 1) is characterized by the occurrence of several Pleistocene marine terraces (Miyauchi et al., 1994). According to Dumas and Raffy (2004), the inner margin of the terrace hosting shells of S. bubonius, referable to MIS 5.5 (125 ka), is located at altitudes between 130 and $180 \mathrm{~m}$. A detailed structural survey of the area revealed that the elevation of the MIS 5.5 terrace steps abruptly passing from NW (130-140 m, Bovetto-Ravagnese area) to SE ( $181 \mathrm{~m}$, Capo dell'Armi area) across the Armo normal fault (Fig. 8). This occurrence is interpreted as reflecting an offset of the MIS 5.5 terraced deposits by the Armo fault, with the displaced portions of the same terrace resting in the hanging-wall and in the footwall of the fault (Fig. 8). The cumulative uplift rate varies from about $1 \mathrm{~mm} / \mathrm{y}$ in the hanging-wall to $1.4 \mathrm{~mm} / \mathrm{y}$ in the footwall.

The main Holocene morphological feature in this coastal sector is represented by a well preserved beach rock (Fig. 7c), developed from Capo Pellaro to Melito di Porto Salvo, with a $\sim 25 \mathrm{~km}$ linear extent along the coast (inset in Fig. 8). The beach rock forms a sedimentary body whose bottom reaches a $-15 \mathrm{~m}$ depth (Fig. 7d), and with top up to $3 \mathrm{~m}$ high between the villages of Lazzaro and Capo dell'Armi. The beach rock body is organized into well developed layers dipping gently (at $5-10^{\circ}$ ) toward the sea. The surface of the beach rock shows clear abrasional furrows, indicating a former wave-zone position (Pirazzoli et al., 1997). Clasts included in the deposit range in size from fine sands to pebbles, the latter found in the deepest part of the body. The deposit is poor in macroscopic shell fragments, even though thin sections analyses revealed the presence of various planktonic foraminifera and fragments of bryozoa. AMS radiocarbon age determination of a well preserved shell of Hinia sp. collected at $0.7 \mathrm{~m}$ a.s.l. from the beach rock located just south-east of Capo dell'Armi (Fig. 7c) yielded an age of 4870-5137 cal BP (Table 1). 

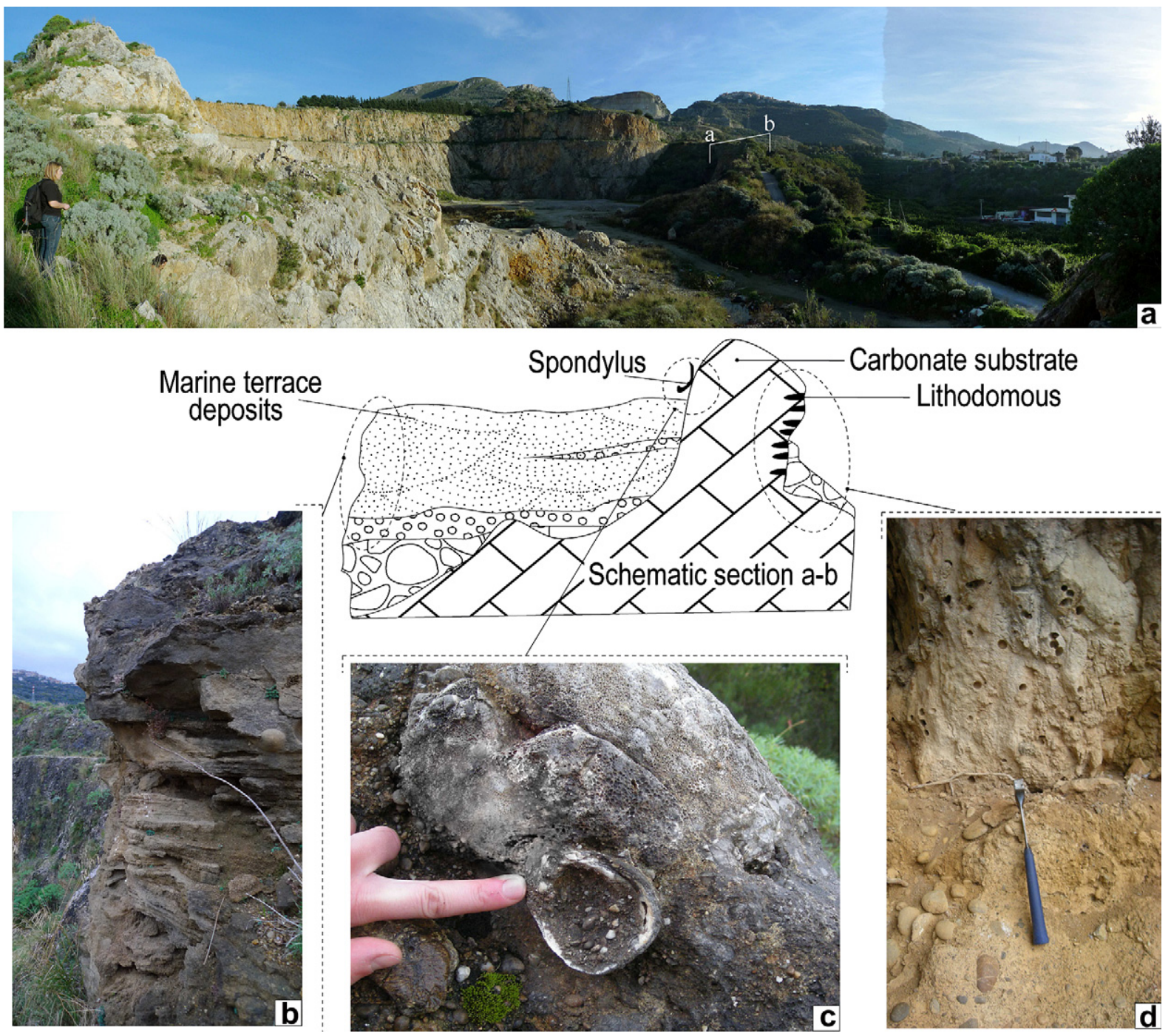

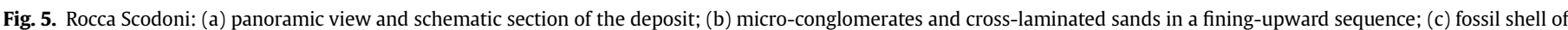
Spondylus sp.; (d) Lithodomus holes in the carbonate substrate.

Capo dell' Armi was known in Greek and Roman times as "Leucopetra" (Greek "white stone") (Thucydides 7, 35; Strabo 6, 259; Cicero, ad Att., 16, 7; Phil. 1,3; Plin., Nat. Hist. 3, 6, 73-74; Tabula Peutingeriana) because of the whitish crystalline rocks flooring the promontory, and was considered a sacred locale (Giangiulio, 1996; Poccetti, 1996; Chilà, 2002). The site was colonized since the Archaic Age. Remains of a settlement and a sanctuary used until the Hellenistic age have been found in the neighborhoods of Saline (Fig. 8). A large Roman villa was located along the right side of the San Vincenzo river (close to Lazzaro), probably coinciding with the later "statio" that is represented in the Tabula Peutingeriana. It is highly likely that the San Vincenzo river mouth (Fig. 8) during the Roman age was a haven for the anchorage of small boats (Schmiedt, 1975; Costamagna, 1991; Chilà, 2002), even if Turano (1970) identifies the bay to the south-east of the promontory as the site of the ancient Leucopetra harbour. The barbarian invasion during the $\mathrm{V}$ century A.D. forced the citizens to move landward leaving the coastal area, even though a renewal of commercial and economical activities took place during the Byzantine age.

Millstones for oil were found at Capo dell'Armi in a partially submerged quarry carved into the beachrock body at elevations of between $0.4 \mathrm{~m} \mathrm{~b} \mathrm{~s} 1$ and $1 \mathrm{~m}$ a.s.l. (Fig. 7e). The millstones are very similar in shape, dimension and extraction techniques to those surveyed at Capo d'Orlando, and they are organized into an exploitation field as well. Several millstones were never finished or extracted. They are elliptical or sub-circular with the major axis ranging in size between $1.10 \mathrm{~m}$ and $1.30 \mathrm{~m}$, the extraction cut is up to $0.25 \mathrm{~m}$ thick and $0.10 \mathrm{~m}$ large. Exposed millstones are well preserved, whereas the submerged ones are strongly eroded although their shape and dimensions can still be readily measured. The lowest elevation of the base of the extraction cut (see transect in Fig. 8) is located at a tide- and pressure-corrected depth of $-0.16 \mathrm{~m}$ (Table 1). Taking into account a functional height of $0.60 \mathrm{~m}$, as for Capo d'Orlando, palaeo-sea level, at the time of use of the field, was $0.76 \mathrm{~m}$ below the present sea level.

\section{Discussion}

The detailed surveys and precise measurements of archaeological and morphological markers can provide an important contribution to characterize the vertical tectonic history of two coastal sectors in Northern Sicily and Eastern Calabria (Table 1). On the other hand, it is possible, in areas whose vertical rate of tectonic deformation is well known, to date archaeological sites of uncertain age occurring along the coastline. These kinds of analyses are 


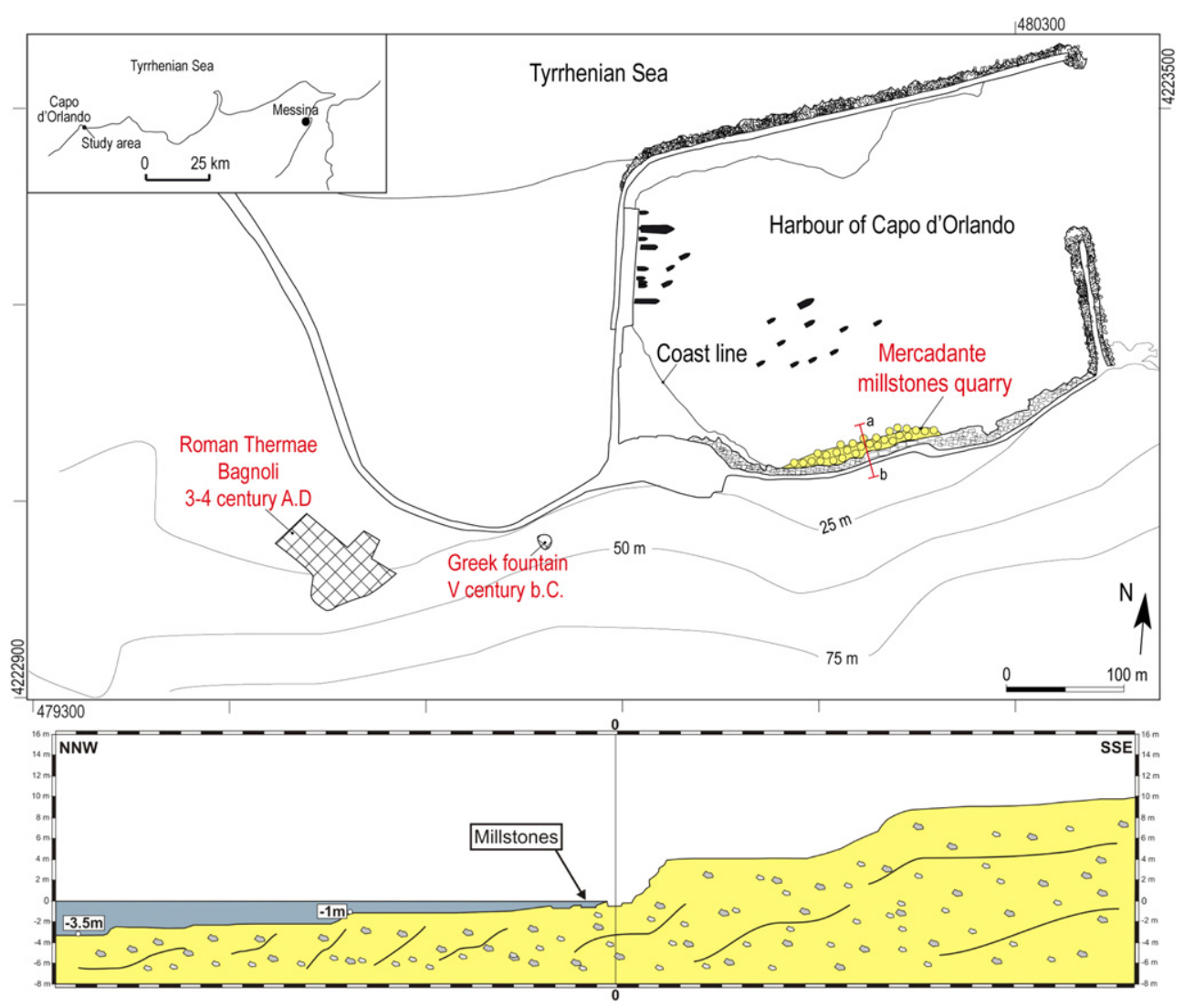

Fig. 6. Sketch map of the main archaeological sites close to the Capo d'Orlando harbour (location in Fig. 3) and transect of the Mercadante millstone quarry.

strictly related to the possibility of accurately estimating the functional height of the archaeological marker at the time of its construction and use (see Lambeck et al., 2004; Antonioli et al., 2007; Scicchitano et al., 2008).

As regards the age, millstones for oil surveyed at Capo d'Orlando and Capo dell'Armi are very similar in shape, dimension, extractive techniques (Chilà, 2002) and present position respect to the mean sea level. Unfortunately, it is not possible to obtain a precise chronological attribution of the Capo d'Orlando and Capo dell'Armi millstones based only on archaeological data. Considering typology and size, the millstones could cover a time span between the Hellenistic age (from 331 B.C.) or Late Republican Roman age (II-I century B.C.) at least to the XVII century A.D, that is from 2300-2100 to 300 BP. Since chronological constraints are weak, vertical tectonic displacement rates obtained by geomorphologic markers were used to place age estimates on the studied millstones.

Attention is focused on the marine terraces that border the coastal area between Capo d'Orlando and Acquedolci (Fig. 3). Taking into account the radiometric determination performed on the continental mammal deposit found at Acquedolci $(200 \pm 40 \mathrm{ka}$, Bada et al., 1991) and considering that this continental deposit lies on a marine platform located at $120 \mathrm{~m}$ a.s.l. (Bonfiglio, 1989), it is evident that the high-stand responsible for the development of the terrace must be older than the mammal remains, and it could be related to MIS 7. Stratigraphic and morphologic correlations between the terrace directly below and the terrace of Rocca Scodoni, located in the Capo d'Orlando area (Figs. 3 and 4), allow attribution of this latter terrace to MIS 5.5. Taking into account that its inner margin is located at an elevation range of 45-60 m, a longterm uplift rate of $\sim 0.3-0.45 \mathrm{~mm} / \mathrm{y}$ can be estimated. Tentatively, it is possible to estimate the shorter-term rate of tectonic uplift for the area of Capo d'Orlando by considering different ages for the Mercadante millstone quarry, surveyed at a maximum depth of $0.09 \mathrm{~m} \mathrm{~b} \mathrm{~s} 1$ (measured at the base of the extraction cut and corrected for tide and pressure). Various estimations of uplift rates were derived by attributing different ages (1000, 1500 and $2300 \mathrm{BP}$ ) and a functional height of $0.60 \mathrm{~m}$ to the millstone field. The tectonic uplift can be evaluated as the difference between the observed local palaeo-sea level positions and the predicted sealevel curve for the same locality (Lambeck et al., 2011) at the different model ages. This exercise results in uplift rates of -0.20 , $0.10,0.32 \mathrm{~mm} / \mathrm{y}$ for the last 1000,1500 and $2300 \mathrm{BP}$, respectively (Table 2). Comparing these values to the uplift rate obtained by geomorphologic marker, the older, Hellenistic age can be reasonably attributed to the Capo d'Orlando quarry because of the broadly similar rate estimate. Taking into account that the MIS 5.5 terrace and the quarry are located at the hanging-wall and at the footwall of the Pleistocene Capo d'Orlando fault, respectively, and that no historical seismicity can be attributed to this structure (Working Group CPTI, 2004), the comparable values of long$(\sim 0.3-0.45 \mathrm{~mm} / \mathrm{y})$ and short-term $(\sim 0.3 \mathrm{~mm} / \mathrm{y})$ estimated uplift rates suggest that this structure is inactive and that uplifting is related to regional processes only.

The estimation of relative sea-level change and uplifting history at Capo dell'Armi is more complicated. Millstones are located $\sim 0.2 \mathrm{~m}$ below the present sea level and are carved into a Holocene beach rock which reaches a maximum elevation of $\sim 3 \mathrm{~m}$ in the area of the millstone field (Fig. 8). Radiocarbon dating of a fossil shell of Hinia sp. collected from the beachrock at a tide-corrected elevation of $0.5 \mathrm{~m}$ a.s.l., yielded an age of 4870-5137 cal BP. Taking into account that this gastropod typically lives in very shallow 

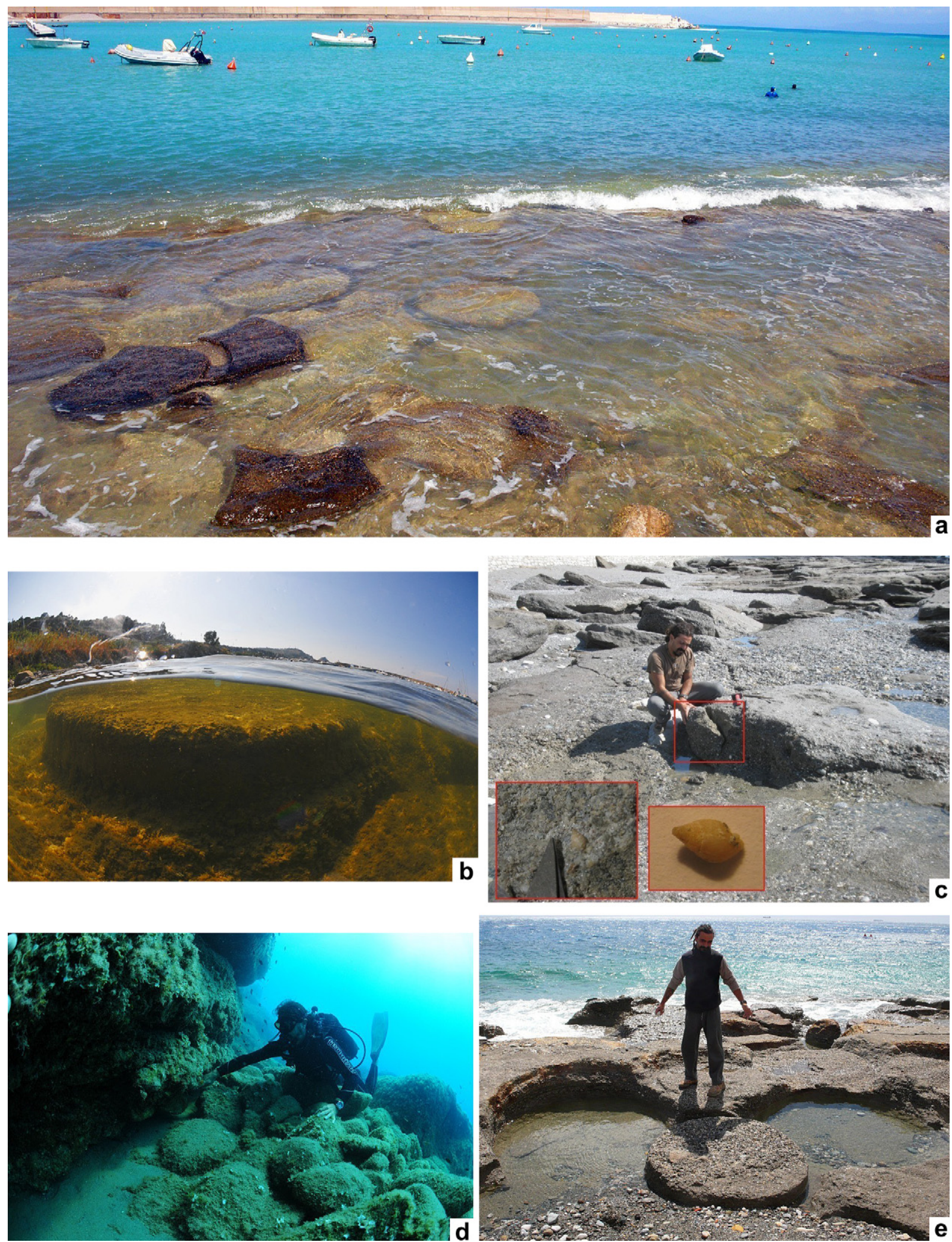

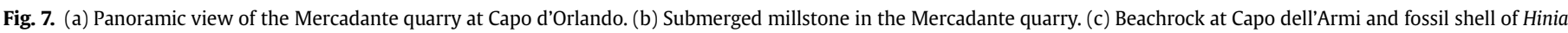
sp. collected inside the deposit. (d) Submerged bottom of the beachrock at Capo dell'Armi. (e) Millstone quarry at Capo dell'Armi.

beach environments, an elevation error of $\pm 1 \mathrm{~m}$ was adopted. Comparing elevation and age with the predicted sea-level curve (Lambeck et al., 2011), an uplift rate of $1.0 \pm 0.2 \mathrm{~mm} / \mathrm{y}$ can be estimated for the last $5 \mathrm{ka}$ BP. This value is comparable, within error, with long-term estimation obtained using the elevation of the MIS 5.5 terrace both in the hanging-wall and footwall of the Armo fault (Fig. 1). As regards the archaeological markers, as at Capo d'Orlando, various estimations of uplift rates were derived by 


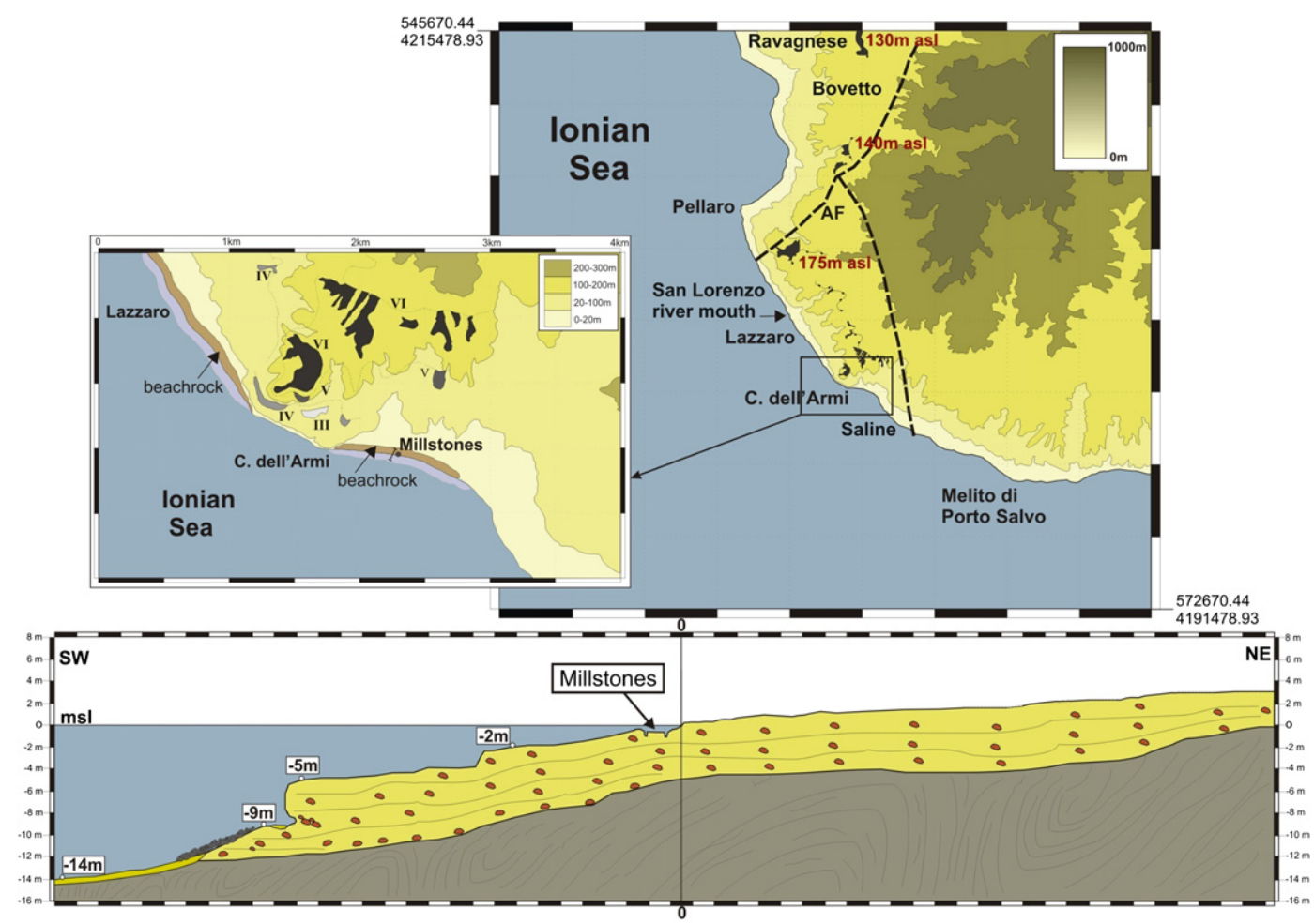

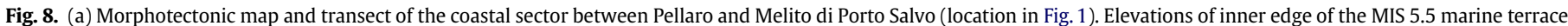
are reported (from Atzori et al., 1983; Dumas and Raffy, 2004, modified).

attributing the same different ages (1000, 1500 and 2300 BP) and functional heights of $0.60 \mathrm{~m}$ to the millstone field (Table 2). None of the considered scenarios fit with the uplift-rate value obtained by geological markers, even though the oldest age attribution yields the highest value of uplift rate $(\sim 0.3 \mathrm{~mm} / \mathrm{y}$, Table 2$)$. Taking into account that the Capo dell'Armi millstones seem to be coeval to those at Capo d'Orlando, an age attribution of 2300 BP seems reasonable.

The different values of uplift rate obtained by geological and archaeological markers at Capo dell'Armi could be explained by an uplift scenario characterized by a cyclical occurrence of coseismic events related to the activity of the Armo fault. The MIS 5.5 terrace and the 5000 a beachrock have been probably affected by regional uplifting and fault-related footwall deformation. Taking into account the Hellenistic age of the millstone quarry and its location at the hanging-wall of a splay of the Armo fault (Fig. 8), the present elevation of the quarry could be explained by local subsidence related to the activity of this splay. Inherent in this explanation is the implication that, in the short term, the splay has focused slip instead of the main branch located to the NW toward Pellaro, which has accommodated the major offset of the MIS 5.5 terrace (Fig. 8). In

Table 2

Estimations of uplift rate for the studied sites, obtained by attributing different ages to the archaeological markers. Values of marker elevation, functional height and palaeo-sea level are reported in Table 1.

\begin{tabular}{llll}
\hline $\begin{array}{l}\text { Age } \\
\text { attribution } \\
\text { (years) }\end{array}$ & $\begin{array}{l}\text { Predicted } \\
\text { sea level } \\
(\mathrm{m})\end{array}$ & $\begin{array}{l}\text { Uplift rate } \\
(\mathrm{mm} / \mathrm{yr}) \text { in } \\
\text { the Capo } \\
\text { d'Orlando area }\end{array}$ & $\begin{array}{l}\text { Uplift rate } \\
(\mathrm{mm} / \mathrm{yr}) \text { in } \\
\text { the Capo } \\
\text { dell'Armi area }\end{array}$ \\
\hline 1000 & -0.49 & -0.20 & -0.27 \\
1500 & -0.85 & 0.10 & 0.06 \\
2300 & -1.42 & 0.32 & 0.29 \\
\hline
\end{tabular}

the short term, local subsidence may prevail over regional uplift, a fact observed also in Northern Calabria (Ferranti et al., in this issue). Displacement related to the 1908 earthquake caused a coseismic down-warping of the Capo dell'Armi area of about $10 \mathrm{~cm}$ which was documented by the leveling survey of Loperfido (1909). Obviously, this subsidence cannot entirely justify the submerging of a Hellenistic quarry in this area, and further investigations are required to explain the occurrence of millstones holes down to about $0.2 \mathrm{~m}$ b.s.l.

\section{Conclusions}

Analyses of archaeological and geological markers at Capo d'Orlando and Capo dell'Armi yield important implications for the study of relative sea-level changes:

- When precisely dated, millstone quarries can represent a good marker of relative sea-level change in consideration of their strict relation with the shoreline at time of their use. Unfortunately, millstone quarries discovered at Capo d'Orlando and Capo dell'Armi could not be dated with precision. Given the typology and size ( $1.50 \mathrm{~m}$ diameter), their chronological range is very wide, between the Hellenistic (from 331 B.C.) or Late Republican Roman age (II-I century B.C.) at least to the XVII century A.D. (2300-2100 to 300 BP).

- Uplift rates estimated for the Capo d'Orlando area by archaeological and geological markers are comparable, attributing an Hellenistic age to the Mercadante quarry. These rates can be reasonably related to the regional process of uplift of the westernmost sector of the Calabrian Arc, as no active tectonic structures occur in the area.

- Uplift rates estimated for the Capo dell'Armi area by archaeological and geological markers are different. Raised geological 
markers can be related to the combination of regional uplifting and coseismic events related to the activity of the Armo fault. In this context, the minor uplift of the Capo dell'Armi millstone quarry when compared to long-term estimates can be explained by its location at the hanging-wall of a splay of the Armo fault, where historical subsidence phenomena are documented.

\section{Acknowledgements}

We thank Silvia Orioli, Laura Bonfiglio, Antonio Caruso, Sara Paparoni, Annunziata Ollà and Enrico Felici for discussion and assistance in the field. The research was partially funded by VECTOR (VulnErability of the Italian coastal area and marine Ecosystems to Climatic changes and their role in the Mediterranean carbon cycles), by grants from University of Catania (responsible C. Monaco), and by Dipartimento della Protezione Civile-INGV (Seismological project S1, 2007-2009, responsible L. Ferranti).

\section{References}

Acquaviva, R., 1995. Palmenti e frantoi in Sicilia Siracusa.

Adam, J.P., 1984. L'arte di costruire presso i Romani. Materiali e tecniche Albairate (Milano).

Amoruso, A., Crescentini, L., Scarpa, R., 2002. Source parameters of the 1908 Messina Straits, Italy, earthquake from geodetic and seismic data. Journal of Geophysical Research 107 (B4). doi:10.1029/2001JB000434.

Amouretti, M.C., 1986. Le pain et l'huile dans la Grèce antique Paris.

Amouretti, M.C., Brun, J.P., 1993. La production du vin et de l'huile en Méditerranée. Suppl. BCH 26, Athens.

Antonioli, F., Kershaw, S., Rust, D., Verrubbi, V., 2003. Holocene sea-level change in Sicily and its implications for tectonic models: new data from the Taormina area, northeast Sicily. Marine Geology 196, 53-71.

Antonioli, F., Ferranti, L., Lambeck, K., Kershaw, S., Verrubbi, V., Dai Pra, G., 2006. Late Pleistocene to Holocene record of changing uplift-rates in southern Calabria and northeastern Sicily (southern Italy, central Mediterranean Sea). Tectonophysics $422,23-40$.

Antonioli, F., Anzidei, M., Lambeck, K. Auriemma, R., Gaddi, D., Furlani, S., Orrù, P. Solinas, E., Gaspari, A., Karinja, S., Kovačić, V., Surace, L., 2007. Sea level change during the Holocene in Sardinia and in the North-eastern Adriatic (Central Mediterranean sea) from archaeological and geomorphological data. Quaternary Science Reviews 26, 2463-2486.

Antonioli, F., Ferranti, L., Fontana, A., Amorosi, A.M., Bondesan, A., Braitenberg, C., Dutton, A., Fontolan, G., Furlani, S., Lambeck, K., Mastronuzzi, G., Monaco, C., Spada, G., Stocchi, P., 2009. Holocene relative sea-level changes and vertical movements along the Italian coastline. Journal of Quaternary International 231, $37-51$.

Anzidei, M., Esposito, A., Antonioli, F., Benini, A., Tertulliani, A., Del Grande, C. 2006. I movimenti verticali nell'area di Briatico: evidenze da indicatori archeologici marittimi nell'area del terremoto del 1905. In: Guerra, I., Bavaglio, A. (Eds.), 8 settembre 1905 Terremoto in Calabria. Deputazione di Storia Patria per la Calabria. Università della Calabria, Regione Calabria.

Argnani, A., Serpelloni, E., Bonazzi, C., 2007. Pattern of deformation around the central Aeolian Islands: evidence from multichannel seismics and GPS data. Terra Nova 19, 317-323.

Atzori, P., Ghisetti, F., Pezzino, A., Vezzani, L., 1983. Carta geologica del bordo occidentale dell'Aspromonte. S.EL.C.A., Firenze.

Auriemma, R., 2007. Torre S. Sabina. L'approdo ritrovato: appunti di scavo. In: Atti del III Convegno Nazionale di Archeologia Subacquea (Manfredonia, 4-6 ottobre 2007)

Auriemma, R., Solinas, E., 2009. Archaeological remains as sea level change markers: a review. Quaternary International 206, 134-146.

Bada, J.L., Belluomini, G., Bonfiglio, L., Branca, M., Burgio, E., Delitala, L., 1991 Isoleucine epimerization ages of Quaternary mammals from Sicily. Il Quaternario 4 (1a), 49-54.

Balescu, S., Dumas, B., Guérémy, P., Lamothe, M., Lhénaff, R., Raffy, J., 1997. Thermoluminescence dating tests of Pleistocene sediments from uplifted marine shorelines along the southwest coastline of the Calabria Peninsula (southern Italy). Palaeogeography, Palaeoclimatology, Palaeoecology 130, 25-41.

Barone, A., Fabbri, A., Rossi, S., Sartori, R., 1982. Geological structure and evolution of the marine areas adjacent to the Calabrian arc. Earth Evolution Science 3, 207-221.

Beltrame, C., Boetto, G., 1997. Macine da relitti. Archeologia Subacquea. Studi, ricerche e documenti II, 167-196.

Bessac, J.C., 1986. La prospection archéologique des carrières de pierre de taille: approche méthodologique. Aquitania 4, 151-171.
Bianca, M., Monaco, C., Tortorici, L., Cernobori, L., 1999. Quaternary normal faulting in southeastern Sicily (Italy): a seismic source for the 1693 large earthquake. Geophysical Journal International 139, 370-394.

Billi, A., Barberi, G., Faccenna, C., Neri, G., Pepe, F., Sulli, A., 2006. Tectonics and seismicity of the Tindari Fault System, southern Italy: crustal deformations at the transition between ongoing contractional and extensional domains located above the edge of a subducting slab. Tectonics 25, 1-20.

Boardman, J., 1958-1959. Excavations at Pindakas in Chios. The Annals of the British School at Athens 53-54, 301-308.

Boccaletti, M., Nicolich, R., Tortorici, L., 1990. New data and hypothesis on the development of the Tyrrhenian basin. Palaeogeography, Palaeoclimatology, Palaeoecology 77, 15-40.

Bonanno, C., 2004. Le necropoli. In: Spigo, U. (Ed.), Archeologia a Capo d'Orlando. Studi per l'Antiquarium, Milazzo (Messina), pp. 79-90.

Bonfiglio, L., 1972. Il Tirreniano di Bovetto e Ravagnese presso Reggio Calabria. Quaternaria 16, 137-148.

Bonfiglio, L., 1989. Distribuzione quantitative dei resti di Hippopotamus sp. del deposito di bacino del talus della grotta di S.Teodoro (Acquedolci, Messina, Sicilia). Atti $3^{\circ}$ Simp. Ecol. e Paleoecol., Catania, 12-16 ottobre 1985, 299-317.

Bonfiglio, L., Mangano, G., Pino, P., 2010. The contribution of mammal-bearing deposits to timing late Pleistocene tectonics of Cape Tindari (north eastern Sicily). Rivista Italiana di Paleontologia e Stratigrafia 116 (1), 103-118.

Brun, J.P., 1997. L'introduction des moulins dans les huileries antiques. In: GarciaD. MeeksD (Eds.), Techniques et économie antiques et médiévales. Le temps de l'innovation, Colloque d'Aix-en-Provence (mai 1996), Paris, pp. 69-78.

Busana, M.S., D'Incà, C., Forti, S., 2009. Olio e pesce in epoca romana nell'alto e medio Adriatico. In: Pesavento Mattioli, S., Carre, M.B. (Eds.), Olio e pesce in epoca romana: produzione e commercio nelle regioni dell'Alto Adriatico. Atti Del Convegno, Padova, pp. 37-81.

Carandini, A., 1985. Settefinestre. Una Villa Schiavistica Nell'Etruria Romana. II. La villa nelle sue parti, Modena.

Carbone, S., Lentini, F., Vinci, G., 1998. Carta geologica del settore occidentale de Monti Peloritani (Sicilia nord-orientale). S.EL.CA., Firenze.

Catalano, S., Di Stefano, A., 1997. Sollevamenti e tettogenesi pleistocenica lungo il margine tirrenico dei Monti Peloritani: integrazione dei dati geomorfologici, strutturali e biostratigrafici. Il Quaternario 10, 337-342.

Catalano, S., De Guidi, G., 2003. Late Quaternary uplift of northeastern Sicily: relation with the active normal faulting deformation. Journal of Geodynamics $36,445-467$

Chilà, D.M., 2002. Il versante orientale dello Stretto di Messina: Rhegium, il suo porto e il sistema di approdi viciniori. In: Gentili, B., Pinzone, A. (Eds.), Messina e Reggio nell'antichità: storia, società e cultura. Atti del Convegno della S.I.S.A.C. (Messina-Reggio Calabria 24-26/5/1999), Pelorias, vol. 9. Collana del Dipartimento di Scienze dell'Antichità dell'Università di Messina, pp. 441-454.

Comet, G., 1993. Le vin et l'huile en provence médiévale, essai de bilan. In: Amouretti, M.C., Brun, J.P. (Eds.), La production du vin et de l'huile en Méditerranée, Suppl. BCH 26, Athens, pp. 343-358.

Costamagna, L., 1991. La sinagoga di Bova Marina nel quadro degli insediamenti tardoantichi della costa Ionica meridionale della Calabria. MEFR Moyen Age 103 (2), 611-620.

D'Agostino, N., Selvaggi, G., 2004. Crustal motion along the Eurasia-Nubia plate boundary in the Calabrian arc and Sicily and active extension in the Messina Straits from GPS measurements. Journal of Geophysical Research 109 (B11402).

De Guidi, G., Catalano, S., Monaco, C., Tortorici, L., 2003. Morphological evidence of Holocene coseismic deformation in the Taormina region (NE Sicily). Journal of Geodynamics 36, 193-211.

Dewey, J.F., Helman, M.L., Turco, E., Hutton, D.H.W., Knott, S.D., 1989. Kinematics of the western Mediterranean. In: Coward, M.P., Dietrich, D., Park, R.G. (Eds.), Alpine Tectonics. Geological Society of London Special Publication, vol. 45, pp. 265-283.

Dumas, B., Gueremy, P., Lhenaff, R., Raffy, J., 1982. Le soulèvement quaternaire de la Calabre méridionale. Revue Géologie Dynamique et Géographie Physique 23, 27-40.

Dumas, B., Gueremy, P., Lhenaff, R., Raffy, J., 1987. Decouverte a 157 m d'altitude pres de Nocella (Italie du Sud), du plus haut rivage tyrrhenien connu a ce jour. Comptes rendus de l'Academie des Sciences, Paris 305 (11), 139-142.

Dumas, B., Raffy, J., 2004. Late Pleistocene tectonic activity deduced from uplifted marine terraces in Calabria, facing the Strait of Messina. Quaternaria Nova VIII, 79-99.

Dworakowska, A., 1975, Quarries in Ancient Greece Warszawa.

Felici Buscemi, G., Felici, E., 2004. Latomie costiere tra Punta Castelluzzo e Brucoli (Augusta). Daidalos 6, 159-188

Ferranti, L, Pagliarulo, R., Antonioli, F., Randisi, A. Relative sea level changes and differential tectonic motion at the ancient Sybaris (Calabria, southern Italy). Quaternary International, in this issue.

Ferranti, L., Antonioli, F., Mauz, B., Amorosi, A., Dai Pra, G., Mastronuzzi, G. Monaco, C., Orrù, P., Pappalardo, M., Radtke, U., Renda, P., Romano, P., Sansò, P. Verrubbi, V., 2006. Markers of the last interglacial sea level highstand along the coast of Italy: Tectonic implications. Quaternary International 145-146, 30-54.

Ferranti, L., Monaco, C., Antonioli, F, Maschio, L., Kershaw, S., Verrubbi, V., 2007. The contribution of regional uplift and coseismic slip to the vertical crustal motion in the Messina Straits, Southern Italy: evidence from raised Late Holocene shorelines. Journal of Geophysical Research 112, B06401.

Ferranti, L., Oldow, J.S., D'Argenio, B., Catalano, R., Lewis, D., Marsella, E. Avellone, G., Maschio, L., Pappone, G., Pepe, F., Sulli, A., 2008. Active deformation in southern Italy, Sicily and southern Sardinia from GPS velocities of the 
Peri-Tyrrhenian geodetic Array (PTGA). Bollettino Società Geologica Italiana 127, 299-316.

Firth, C., Stewart, I., McGuire, W.M., Kershaw, S., Vita-Finzi, C., 1996. Coastal elevation changes in eastern Sicily: implications for volcano instability at Mount Etna. In: McGuire, W.M., Jones, A.P., Neuberg, J. (Eds.), Volcano Instability on the Earth and Other Planets. Geological Society of London Special Publication, vol. 110, pp. 153-167.

Flemming, N.C., 1969. Archaeological evidence for eustatic changes of Sea level and Earth movements in the western Mediterranean in the last 2000 Years. Geological Society of America Special Paper 109, 1-125.

Flemming, N.C., Webb, C.O., 1986. Tectonic and eustatic coastal changes during the last 10,000 years derived from archaeological data. Zeitschrift fur Geomorphologie 62, 1-29.

Foxhall, L., 1993. Oil extraction and processing equipment in classical Greece. In: Amouretti, M.C., Brun, J.P. (Eds.), La production du vin et de l'huile en Méditerranée, Suppl. BCH 26, Athens, pp. 183-199.

Frepoli, A., Amato, A., 2000. Spatial variation in stresses in peninsular Italy and Sicily from background seismicity. Tectonophysics 317, 109-124.

Frankel, R., 1993. The trapetum and mola olearia. In: Amouretti, M.C., Brun, J.P. (Eds.), La production du vin et de l'huile en Méditerranée, Suppl. BCH 26, Athens, pp. 477-481.

Ghisetti, F., 1981. Upper Pliocene-Pleistocene uplift rates as indicators of neotectonic pattern: an example from southern Calabria (Italy). Zeitschrift fur Geomorphologie 40, 93-118.

Ghisetti, F., Vezzani, L., 1982. The recent deformation mechanisms of the Calabrian Arc. Earth Evolution Science 3, 197-206.

Ghisetti, F., 1984. Recent deformations and the seismogenic source in the Messina Straits (southern Italy). Tectonophysics 109, 191-208.

Giangiulio, M., 1996. Tra mare e terra. L'orizzonte religioso del paesaggio costiero. In: Prontera, F.(Ed.), La Magna Grecia e il mare. Studi di storia marittima, pp. 251-272.

Gignoux, M., 1913. Les formations marines pliocenes et quaternaires de l'Italie du sud et de la Sicilie. Annales de l'Universite de Lyon 36, 693.

Giunta, G., Luzio, D., Tondi, E., De Luca, L., Giorgianni, A., D’Anna, G., Renda, P. Cello, G., Nigro, F., Vitale, M., 2004. The Palermo (Sicily) seismic cluster of September 2002, in the seismotectonic framework of the Tyrrhenian Sea-Sicily border area. Annals of Geophysics 47/6, 1755-1770.

Giunta, G., Luzio, D., Agosta, F., Calò, M., Di Trapani, F., Giorgianni, A., Oliveti, E. Orioli, S., Perniciaro, M., Vitale, M., Chiodi, M., Adelfio, G., 2009. An integrated approach to investigate the seismotectonics of northern Sicily and southern Tyrrhenian. Tectonophysics 476, 13-21.

Gliozzi, E., Malatesta, A., 1982. A Megacerine in the Pleistocene of Sicily. Geologica Romana 21, 311-395.

Goes, S., Guiardini, D., Jenny, S., Hollenstein, C., Kahle, H.G., Geiger, A., 2004. A recent tetconic reorganization in the south-central Mediterranean. Earth and Planetary Science Letters 226, 335-345.

Gueguen, E., Tavarnelli, E., Renda, P., Tramutoli, M., 2002. The geodynamics of the southern Tyrrhenian Sea margin as revealed by integrated geological, geophysical and geodetic data. Bollettino Società Geologica Italiana 1, 77-85. Special volume.

Hadjisavvas, S., 1992. Olive Oil Processing in Cyprus from the Bronze Age to the Byzantine Period. SMA 99, Nicosia.

Hollenstein, C., Kahle, H.G., Geiger, A., Jenny, S., Goes, S., Giardini, D., 2003. New GPS constraints on the Africa-Eurasia plate boundary zone in southern Italy. Geophysical Research Letters 30,1-4.

Hugonie, G., 1974. Le relief de la règion de Messine (Sicilie). Méditerranée 1, 43-61.

Hugonie, G., 1979. L'èvolution gèomorphologique de la Sicilie septentrionale. Thèse de Doct. en Lettres, Universite Paris Sorbonne, pp. 1-949.

Hugonie, G., 1982. Mouvements tectoniques et variations de la morphogenèse au Quaternarie en Sicilie septentrionale. Revue, Gèologie Dynamique et Gèographie Physique 23 (1), 3-14.

Incudine, C., 1882. Naso Illustrata, Napoli. Giuffrè Editore, Milano. 1975

Jacques, E., Monaco, C., Tapponnier, P., Tortorici, L., Winter, T., 2001. Faulting and earthquake triggering during the 1783 Calabria seismic sequence. Geophysical Journal International 147, 499-516.

Kastens, K.A., Mascle, J., Auroux, C.A., Bonatti, E., Broglia, C., Channell, J., Curzi, P. Emeis, K.C., Glacon, G., Hasegawa, S., Hieke, W., McCoy, F., McKenzie, J., Mascle, G., Mendelson, J., Mueller, C., Rehault, J.P., Robertson, A., Sartori, R. Sprovieri, R., Torii, M., 1987. Proceedings of the Ocean Drilling program, Tyrrhenian Sea, covering Leg 107 of the cruises of the drilling vessel JOIDES resolution, Malaga, Spain, to Marseille, France, sites 650-656, 26 December 1985-18 February 1986. In: Stewart, Norman, J. (Eds.), Proceedings of the Ocean Drilling Program, Part A: Initial Reports, p. 107.

Kloner, A., Sagiv, N., 1993. The olive presses of hellenistic Maresha, Israel. In Amouretti, M.C., Brun, J.P. (Eds.), La production du vin et de l'huile en Méditerranée. Suppl. BCH 26, Athens, pp. 119-136.

Kozelj, T., Wurch Kozelj, M., 1993. Les transports dans l'Antiquité. In: Francovich, R. (Ed.), Archeologia delle attività estrattive e metallurgiche. V Ciclo di Lezioni sulla Ricerca applicata in Archeologia, Certosa di Pintignano (SI) - Campiglia marittima (LI), 9-21 settembre 1991, Firenze, pp. 97-142.

Lambeck, K., Anzidei, M., Antonioli, F., Benini, A., Esposito, A., 2004. Sea level in Roman time in the Central Mediterranean and implications for recent change. Earth and Planetary Science Letters 224 (3-4), 563-575.

Lambeck, K., Antonioli, F., Anzidei, M., Ferranti, L., Leoni, G., Silenzi, S., 2011. Sea level change along the Italian coasts during Holocene and prediction for the future. Quaternary International 232, 250-257.
Lanzafame, G., Bousquet, J.C., 1997. The Maltese escarpment and its extension from Mt. Etna to the Aeolian Islands (Sicily): importance and evolution of a lithosphere discontinuity. Acta Vulcanologica 9, 113-120.

Lavecchia, G., Ferrarini, F., De Nardis, R., Visini, F., Barbano, M.S., 2007. Active thrusting as a possible seismogenic source in Sicily (Southern Italy): some insights from integrated structural-kinematic and seismological data. Tectonophysics $445,145-167$

Loperfido, A., 1909. Livellazione geometrica di precision eseguita dall'Istituto geografico militare sulla costa orientale della Sicilia, da Messina a Catania, a Gesso ed a Faro Peloro e sulla costa occidentale della Calabria da Gioia Tauro a Melito di Porto Salvo, per incarico del Ministro dell'Agricoltura, Industria e Commercio, Roma, Rel. Comm. R, pp.131-169.

Malinverno, A., Ryan, W.B.F., 1986. Extension in the Tyrrhenian Sea and shortening in the Apennines as a result of arc migration driven by sinking of the lithosphere. Tectonics 5, 227-245.

Matijašić, R., 2007. Impianti antichi per olio e vino in contesto urbano in Istria. Histria Antiqua 15, 13-26.

Mattia, M., Palano, M., Bruno, V., Cannavò, F., Bonaccorso, A., Gresta, S., 2008. Tectonic features of the Lipari-Vulcano complex (Aeolian archipelago, Italy) from 10 years (1996-2006) of GPS data. Terra Nova 20, 370-377.

Mattia, M., Palano, M., Bruno, V., Cannavò, F., 2009. Crustal motion along the Calabro-Peloritano Arc as imaged by twelve years of measurements on a dense GPS network. Tectonophysics 476, 528-537.

Mattingly, D.J., Hitchner, B., 1993. Technical specifications for North African olive presses. In: Amouretti, M.C., Brun, J.P. (Eds.), La production du vin et de l'huile en Méditerranée, Suppl. BCH 26, Athens, pp. 439-462.

Miyauchi, T., Dai Pra, G., Sylos Labini, S., 1994. Geochronology of Pleistocene marine terraces and regional tectonics in the Tyrrhenian coast of South Calabria, Italy. Il Quaternario 7 (1), 17-34.

Monaco, C., Tapponnier, P., Tortorici, L., Gillot, P.Y., 1997. Late Quaternary slip rates on the Acireale-Piedimonte normal faults and tectonic origin of Mt. Etna (Sicily). Earth and Planetary Science Letters 147, 125-139.

Monaco, C., Tortorici, L., 2000. Active faulting in the Calabrian arc and eastern Sicily. Journal of Geodynamics 29, 407-424.

Mongitore, A., 1743. Istoria cronologica de' terremoti in Sicilia. Della Sicilia Ricercata Nelle Cose Più Memorabili, Palermo 2, 345-445.

Moritz, L.A., 1958. Grain-mills and Flour in Classical Antiquity. Oxford University Press, Oxford.

Neri, G., Barberi, G., Oliva, G., Orecchio, B., 2005. Spatial variation of seismogenic stress orientations in Sicily, South Italy. Physics of the Earth and Planetary Interiors 148, 175-191.

Nicolich, R., Cita, M.B., Fabbri, A., Fanucci, F., Torelli, L., Wezel, F.C., 1982. Bacini sedimentari: ricerche geofisiche e di geologia marina. In: P.F. Oceanografia e fondi marini, S.P. Risorse Minerarie. C.N.R., Roma.

Nigro, F., Sulli, A., 1995. Plio-Pleistocene extensional tectonics in the western Peloritani area and its offshore (Northeastern Sicily). Tectonophysics 252, 295-305.

Ollà, A., 2004. Ceramica da Bagnoli - S. Gregorio: importazioni e produzioni locali In: Spigo, U. (Ed.), Archeologia a Capo d'Orlando. Studi per l'Antiquarium, Milazzo (Messina), 109-140.

Orlandos, A.K., 1968. Les matériaux de construction et la technique architectural des anciens Grecs. II partie, Paris.

Pepe, F., Bertotti, G., Cella, F., Marsella, E., 2000. Rifted margin formation in the south Tyrrhenian Sea: a high-resolution seismic profile across the north Sicily passive continental margin. Tectonics 19, 241-257.

Pepe, F., Sulli, A., Agate, M., Di Maio, D., Kok, A., Lo Iacono, C., Catalano, R., 2003. Plio-Pleistocene geological evolution of the northern Sicily continental margin (southern Tyrrhenian Sea): new insights from high-resolution, multi-electrode sparker profiles. Geo Marine Letters 23, 53-63.

Pinzone, A., 2004. Agatirno: spunti di storia istituzionale ed economica. In: Spigo, U. (Ed.), Archeologia a Capo d'Orlando, Studi per l'Antiquarium, Milazzo (Messina).

Pirazzoli, P.A., Mastronuzzi, G., Saliège, J.F., Sansò, P., 1997. Late Holocene emergence in Calabria, Italy. Marine Geology 141, 61-70.

Poccetti, P., 1996. Aspetti linguistici e toponimastici della storia marittima dell'Italia antica. In: Prontera, F. (Ed.), La Magna Grecia e il mare. Studi di storia marittima, Taranto, pp. 35-73.

Pondrelli, S., Salimbeni, S., Ekström, G., Morelli, A., Gasperini, P., Vannucci, G., 2006 The Italian CMT dataset from 1977 to the present. Physics of the Earth and Planetary Interiors 159, 286-303.

Robillard, D., 1975. Les dépôts quaternaires du versant tyrrhènien de la Sicile (secteur d'Aquedolci-Capo d'Orlando): stratigraphie et tectonique. D.E.A. Universitè des Sciences et Techniques de Lille.

Rockwell, P., 1992. Lavorare la pietra. Manuale per l'archeologo, Roma.

Rosada, G., 2007. Torcularia: tra fonti e archeologia. Histria Antiqua 15, 213-228.

Rust, D., Kershaw, S., 2000. Holocene tectonic uplift patterns in northeastern Sicily: evidence from marine notches in coastal outcrops. Marine Geology 167, 105-126.

Scagliarini Corlàita, D., 1994. La villa di Desenzano. Vicende architettoniche e decorative. In: Studi sulla villa romana di Desenzano, Milano, pp. 43-58.

Schmiedt, G., 1966. Antichi porti d'Italia. I porti delle colonie greche. L'Universo XLVI, 253-296.

Schmiedt, G., 1972. Linea di costa della Sicilia orientale compresa fra la foce del fiume Simeto ed il Capo Ognina. Il livello antico del Mar Tirreno, II, 201-221.

Schmiedt, G., 1975. Antichi Porti D'Italia. Gli Scali Fenicio-punici. I porti della Magna-Grecia, Firenze.

Scibona, G., 1985. Capo d'Orlando in B.T.G.C. (a cura di G. Nenci e G. Vallet), IV, Roma, pp. 426, s.v. 
Scicchitano, G., Antonioli, F., Castagnino Berlinghieri, E.F., Dutton, A., Monaco, C., 2008. Submerged archaeological sites along the Ionian coast of south-eastern Sicily (Italy) and implications with the relative sea level change during the late Holocene. Quaternary Research 70, 26-39.

Spigo, U., 1995. Capo d'Orlando: il complesso termale di età imperiale romana di Bagnoli - S. Gregorio. Scavi 1987-1992. In: Atti dell'VIII Congresso Internazionale di Studi sulla Sicilia Antica, pp. 1027-1037.

Spigo, U., 2004a. Il territorio di Capo d'Orlando nell'Antichità: nota introduttiva. In: Spigo, U. (Ed.), Archeologia a Capo d'Orlando. Studi per l'Antiquarium, Milazzo (Messina), pp. 11-16.

Spigo, U., 2004b. Il complesso termale di località di Bagnoli - S. Gregorio. In: Spigo, U. (Ed.), Archeologia a Capo d'Orlando. Studi per l'Antiquarium, Milazzo (Messina), pp. 91-108.

Spigo, U., Ollà, A., Capelli, C., 2004. La ceramica di produzione locale dalle terme di Bagnoli-S. Gregorio a Capo d'Orlando (ME). In: Malfitana, D., Poblome, J., Lund, J. (Eds.), Old Pottery in a New Century. Innovating Perspectives on Roman Pottery Studies. Atti del Convegno Internazionale di Studi (Catania, 22-24 aprile 2004), pp. 451-464.

Stewart, I.S., Cundy, A., Kershaw, S., Firth, C., 1997. Holocene coastal uplift in the Taormina area, northeastern Sicily: implications for the southern prolongation of the Calabrian seismogenic belt. Journal of Geodynamics 24, 37-50.
Stuiver, M., Reimer, P.J., Reimer, R., 2005. Calib radiocarbon calibration, execute version 5.0.2 html. http://calib.qub.ac.uk/calib.

Tortorici, G., Bianca, M., De Guidi, G., Monaco, C., Tortorici, L., 2003. Fault activity and marine terracing in the Capo Vaticano area (southern Calabria) during the Middle-late Quaternary. Quaternary International 101-102, 269-278.

Tortorici, L., Monaco, C., Tansi, C., Cocina, O., 1995. Recent and active tectonics in the Calabrian arc (Southern Italy). Tectonophysics 243, 37-55.

Trincardi, F., Cipolli, M., Ferretti, P., La Morgia, J., Ligi, M., Marozzi, G., Palumbo, V. Taviani, M., Zitellini, N., 1987. Slope basin evolution of the Eastern Tyrrhenian margin: preliminary report. Giornale di Geologia 49, 1-9.

Turano, C., 1970. Leucopetra. Archeologia Classica 22, 164-200.

Valensise, G., Pantosti, D., 1992. A 125 kyr-long of geological record of seismic source repeatability: the M.S.s (southern Italy) and the 1908 earthquake (MS 71/2). Terra Nova 4, 472-483.

Westaway, R., 1993. Quaternary uplift of southern Italy. Journal of Geophysical Research 98, 21,741-21,772.

Working Group CPTI, 2004. Catalogo Parametrico dei Terremoti Italiani, versione 2004 (CPTI04). INGV, Bologna. http://emidius.mi.ingv.it/CPTI04.

Wortel, M.J.R., Spackman, W., 2000. Subduction and slab detachment in the Mediterranean - Carpathian region. Science 290, 1910-1917. 